\title{
AVRUPA INSAN HAKLARI SÖZLEŞMESİ KORUMA MEKANIZMASINDA REFORM: 14. Protokol Mahkemenin İş Yükü Derdine Deva Olur mu?
}

\author{
(Reforming the Control Mechanism of the European
}

Convention on Human Rights: Will Protocol No:14 be a

Remedy for the Workload Problem of the European Court of Human Rights?)

Avrupa İnsan Hakları Sözleşmesinin koruma mekanizmasında değişiklik yapılmasını öngören 14. Protokol 13 Mayıs 2004 tarihinde Strasbourg'da imzaya açılmış ve aynı gün Konsey üyesi pek çok ülke tarafindan imzalanmıştır. Protokolün iki yıl içinde yürürlüğe girmesi öngörülmüştür ${ }^{1}$. $\mathrm{Bu}$ yazıda Protokolün öngördüğü değişikliklerin incelenmesi amaçlanmaktadır. Ancak değişikliklerin içeriğine geçmeden önce değişiklik ihtiyacını ortaya çıkaran nedenlere ve Protokolün hazırlık sürecine k1saca değinilecektir.

\section{Reform İhtiyact}

1950 yılında kabul edilen Avrupa İnsan Hakları Sözleşmesi (AİHS) kurduğu koruma mekanizması ile uluslararası hukuk ve insan haklarının korunması alanında devrim sayılabilecek yenilikler getirmiştir. $\mathrm{Bu}$

\footnotetext{
${ }^{*}$ Kırıkkale Üniversitesi, Hukuk Fakültesi, Anayasa Hukuku Anabilimdalı Öğretim Üyesi ${ }^{1}$ Avrupa Konseyi Bakanlar Komitesinin 12-13 Mayıs 2004 tarihinde yapılan 114. Bakanlar toplantısında 'Avrupa İnsan Hakları Sözleşmesinin Ulusal ve Avrupa Düzeyinde Uygulanmasını ve Etkinliğini Sağlama' Bildirgesi kabul edilmiştir. Bu bildirgede üye devletler reformun aciliyetine vurgu yaparak 14. Protokolü iki yıl içinde onaylayacaklarını bildirmişlerdir. Explanatory Report, $\S 32$
} 
mekanizma, bir taraftan Sözleşmenin uygulanmasını denetleyecek iki ulusalüstü organ (Avrupa İnsan Hakları Komisyonu ve Avrupa İnsan Hakları Mahkemesi) kurarak devletlerin kendi vatandaşlarına karşı olan işlemlerini ulusalüstü denetime tabi hale getirmiş, diğer taraftan bireylere Komisyona başvuru hakkı tanıyarak bireyleri de uluslararası hukukun süjesi haline getirmiştir. Zaman içinde ortaya çıkan ihtiyaçlar, sistemde değişiklik yapan Protokollerin kabul edilmesi yoluyla karşılanmaya çalışılmıştır. Başlangıçta devletlerin ihtiyarına bırakılan koruma mekanizmasına başvuru hakk1 ve Mahkemenin yarg1 yetkisi 1998 yılında yürürlüğe giren 11. Protokol ile zorunlu hale getirilmiştir. 11. Protokol Sözleşmenin koruma mekanizmasını esaslı şekilde değiştirmiştir. Öncelikle yarı-zamanlı (part-time) çalışan iki organ (Komisyon ve Mahkeme) yerine, tam zamanlı (full-time) çalışan tek bir Mahkeme kurulmuş ve bu Mahkemeye bireysel başvuru ve Mahkemenin yarg1 yetkisi Sözleşmeye taraf tüm devletler açısından zorunlu hale getirilmiştir. Böylece tüm taraf devletlerde yaşayan bireyler Sözleşme ve Protokollerinde korunan haklarının ihlal edilmesi halinde Mahkemeye başvurma hakkına kavuşmuştur. Bu gelişme Sözleşmeye taraf devlet sayısında 1990'dan sonra meydana gelen artışla birlikte dikkate alındığında Mahkemenin önüne gelen başvuru sayısında anormal bir artışa neden olacağ 1 görülebilir. 1989'da 23 olan Sözleşmeye taraf devlet sayısı bugün 45'e ulaşmıştır. $\mathrm{Bu}$ ülkelerde yaşayan birey sayısı ise 800 Milyonun üzerine çıkmıştır. ${ }^{2}$ Dolayısıyla Sözleşmenin korumasından yararlanan ve Mahkemeye başvuru hakkı bulunan bu bireylerin Sözleşme ile ilgili taleplerine Mahkemenin cevap verebilmesi oldukça zorlaşmıştır.

11. Protokolün temel amacı bir taraftan sistemi basitleştirerek başvuruların incelenme süresini kısaltmak, diğer taraftan da sistemin yargısal niteliğini artırarak koruma mekanizmasının etkinliğini artırmaktı. 11. Protokol, Sözleşmenin koruma mekanizmasını tamamen yargısal bir niteliğe büründürmüştür. Bu çerçevede Avrupa İnsan Hakları Komisyonu tamamen ortadan kaldırılırken, Avrupa Konseyi Bakanlar Komitesinin de yarı-yargısal nitelikteki işlevlerine son verilmiş ve böylece Sözleşmeye uygunluk denetimi sadece Avrupa İnsan Hakları Mahkemesi tarafindan gerçekleştirilen yargısal bir işlev haline gelmiştir ${ }^{3}$. Aşağıda görüleceği gibi reform çalışmaları sırasında denetim mekanizmasının bu yargısal niteliğinin bozulmamasına büyük özen gösterilmiştir. Böylece hem bireyler açısından Mahkemeye ulaşmak kolaylaşmış hem de başvuruların incelenmesi eskiye göre çok daha basit bir usulle yürütüldüğünden çok daha kısa sürede karar vermek mümkün hale gelmiştir.

\footnotetext{
${ }^{2}$ Council of Europe, Explanatory Report to the CETS 194 (Protocol No.14 to the Convention for the Protection of Human Rights and Fundamental Freedoms, amending the control system of the Convention) (bundan sonra ER), §4

${ }^{3}$ Ibid, $\$ 6$
} 
Sistemde meydana gelen verimlilik artışı bazı rakamlarla kolayca ortaya konulabilir. Mesela 1998 yılına kadar kırk dört yılda Mahkeme ve Komisyonun vermiş olduğu toplam karar sayısı 38389 iken tek Mahkeme 1998-2003 arasında beş yılda toplam 61633 karar vermiştir ${ }^{4}$. Ancak buna rağmen başvuru sayısında meydana gelen devasa artış nedeniyle Mahkemenin mevcut sistemle incelemelerine devam etmesi halinde bu is yükünün altından kalkmasının ve insan haklarının korunmasında etkinliğini ve saygınlığgıı sürdürmesinin olanaksız olduğu 11. Protokolün yürürlüğe girmesinden hemen kısa bir süre sonra anlaşılmış ve sistemde reform kaçınılmaz hale gelmiştir. Başvuru sayısında meydana gelen artışa kısaca göz atılırsa, mesela 1990 y1lında 5279 olan y1llık başuru sayısının 1994'te 10335 'e, 1998 'de 18164 'e ve 2003 yilında 39 000'in üzerinde bir rakama ulaştı̆g 1 görülmektedir ${ }^{5} .2003$ yılı sonunda Mahkemenin önündeki dosya sayısının 65 000'in üzerinde olduğu bildirilmiştir.

Mahkemenin iş yükündeki artışın nedeni sadece yeni devletlerin Sözleşmeye katılmaları değil, aynı zamanda mevcut taraf devletlerin yeni hakları düzenleyen Protokollere taraf olması ve ülke kamuoylarının Sözleşmede düzenlenen haklar ve başvuru olanakları konusunda giderek daha fazla bilgi sahibi olmalarının da etkili olduğu görülmektedir. Başvurulardaki artma eğiliminin gelecek yıllarda da devam edeceği öngörülmektedir. $\mathrm{Bu}$ öngörünün nedenleri arasında taraf devletlerin Protokollere katılımlarının artması ve kamuoylarının Sözleşme konusunda bilinçlenmelerinin yanı sıra özellikle eşitlik hakkını düzenleyen 12. Protokolün yürürlüğe girmesinin getireceği artışa dikkat çekilmektedir. $\mathrm{Bu}$ manzara mevcut durumun sürdürülemez olduğunu ortaya koymaktadır. Mahkemenin insan haklarının korunmasındaki etkinliğini ve saygınlığını sürdürebilmesi sistemin bu iş yükünü kaldıracak şekilde yeniden yapılandırılmasına bağlıdır. 14. Protokolün amacı bu soruna bir çözüm bulmaktır. 14. Protokolün getirdiği yeniliklerin neler olduğunu incelemeye başlamadan önce kısaca protokolün hazırlanma sürecine göz atmak aydınlatıcı olacaktır.

\section{14. Protokolün Hazırlanma Süreci}

Protokolün hazırlık serüveninin başlangıcı dört y1l önceye, 4 Kasım 2000 tarihinde Sözleşmenin imzaya açılışının 50. yılı nedeniyle Roma'da yapılan İnsan Hakları Avrupa Bakanlar Konferansına dayanmaktadır. Bu Konferansta ele alınan gündem başlıklarından birisi de 'İnsan Haklarının Ulusal ve Avrupa Düzeyinde Korunmasına Yönelik Kurumsal ve İşlevsel Düzenlemeler' başlığını taşımaktaydı. Bu başlık altında ele alınan

\footnotetext{
${ }^{4}$ Survey of Activities 2003

${ }^{5} \mathrm{ER}, \S 5$

${ }^{6}$ Ibid.
} 
konulardan birisi ise 'Avrupa İnsan Hakları Mahkemesinin Etkinliğinin Sağlanması' şeklinde belirlenmişti. Böylece Mahkemenin karşılaştı̆̆ problemler bakanlar düzeyinde tartışılma imkanı bulmuş ve konferans sonuç bildirgesinde Mahkemenin hızla artan iş yüküne dikkat çekilerek Mahkemenin işlevlerini yerine getirebilmesi için alınması gereken acil önlemlerin bir an önce tespit edilmesi için Avrupa Konseyi Bakanlar Komitesine bir çağrı yapılmıştır. ${ }^{7} \mathrm{Bu}$ çağrıyı dikkate alan Bakanlar Komitesi, bir yandan daha önce kurulmuş olan İrtibat Komitesi (Liaison Committee) ile çalışmalara hız verirken diğer taraftan Mahkemenin 2001 yılı ek bütçe taleplerini incelemek üzere ad hoc bir Çalışma Grubu (Working Party) oluşturmuştur. Çalışma grubu raporu Mahkemenin orta dönem ihtiyaçları ve yapılması gerekenler hakkında geniş kapsamlı bir çalışma yapılması gereğine dikkat çekerek bir Değerlendirme Grubu (Evaluation Group) oluşturulmasını önermiştir. ${ }^{8}$ Şubat 2001'de Bakanlar Komitesi yardımcıları tarafından oluşturulan Değerlendirme Grubu raporunu 27 Eylül 2001 tarihinde Bakanlar Komitesine sunmuştur. ${ }^{9}$

Aynı dönemde İnsan Hakları Yönlendirme Komitesi (Steering Committee for Human Rights [CDDH]) de kendi içinde bir İnsan Hakları Koruma Mekanizmasını Güçlendirme İzleme Grubu (Reflection Group) oluşturarak çalışma başlatmış ve grup tarafindan hazırlanan faaliyet raporu ${ }^{10}$ değerlendirilmek üzere Haziran 2001 tarihinde Değerlendirme Grubuna sunulmuştur. Bu raporlarda yer alan öneriler hem Bakanlar Komitesi hem de Mahkeme tarafindan ciddiyetle değerlendirilmiş, Bakanlar Komitesi tarafından Mahkemenin bütçesi önemli ölçüde artırılarak yeni hukukçu ve personel istihdamına olanak tanınmıştır. Mahkeme de tüm yukarıda bahsedilen çalışmaları dikkate alarak kendi çalışma yönteminde önemli değişikliklere gitmiş, Mahkeme İçtüzüğünde 2002 ve 2003' te iki kez esaslı değişiklik yapmıştır ${ }^{11}$.

$\mathrm{Bu}$ raporlarda yer alan önerilerden bir kısmı sadece Mahkemenin ve yazı işlerinin çalışma yöntemlerinde değişiklik yapılmasını içeren dolayısıyla uygulanması için Sözleşmede değişiklik yapılmasına gerek olmayan tedbirleri içermekteydi. Bir kısmı ise taraf devletler tarafından uygulanması gereken tedbirlerdir. Bunun yanında bazıları da Sözleşmede

\footnotetext{
${ }^{7}$ EG Court(2001)1

${ }^{8}$ Final Report of the Working Party "Three Years' Work for the Future" (Council of Europe, Strasbourg, 2000)

${ }^{9}$ Report of the Evaluation Group to the Committee of Ministers on the European Court of Human Rights, (EG Court(2001)1)

${ }^{10}$ Steering Committee for Human Rights (CDDH), Reflection Group on the Reinforcement of the Human rights Protection Mechanism (CDDH-GDR), Activity Report, (CDDH-GDR (2001) 010), 15 June 2001

${ }_{11}$ Mahkeme Genel Kurulunun (Plenary Court) 17 Haziran ve 8 Temmuz 2002 tarihli toplantılarında İç tüzükte önemli değişiklikler yapmış daha sonra tekrar 7 Temmuz 2003 tarihli toplantısında yapılan değişiklikler 1 Kasım 2003 tarihinde yürürlüğe girmiştir.
} 
değişiklik yapılmasını gerektiriyordu. Serdedilen görüşleri incelenmeye değer bulan Bakanlar Komitesi 8 Kasım 2001 tarihindeki 109'uncu toplantısında 'Avrupada İnsan Haklarının Korunmas1- Avrupa İnsan Hakları Mahkemesinin Uzun Dönemde Etkinliğini Garanti Altına Almak' ${ }^{12}$ başlıklı bir bildiri yayınlamıștır. Bu bildiride İnsan Hakları Yönlendirme Komitesi, Değerlendirme Grubu Raporunda yer alan önerileri hayata geçirmek için fizibilite çalıșmaları yapmakla görevlendirilmiștir. Bildiride özellikle belirtilen hususlardan bir tanesi Mahkemeye yapılan başvuruların en uygun incelenme yönteminin ne olması ve başvuruların nasıl elenmesi gerektiğinin tespitidir. Bir diğer husus ise Değerlendirme Grubu raporunda yer alan önerileri inceleyerek uygun olanları için Sözleșme değișiklik tasarılarının hazırlanmasıdır. Yönlendirme Komitesi $(\mathrm{CDDH})$ kendi alt organlarının çalışmaları ile oluşturduğu bu iki husustaki görüş ve önerilerini bir faaliyet raporu şeklinde ${ }^{13}$ Ekim 2002'de Bakanlar Komitesine sunmuştur. Aynı zamanda doküman tüm ilgili kuruluşlara (Mahkeme, Avrupa Konseyi Parlamenterler Meclisi, Avrupa Konseyi Genel Sekreterliği, İnsan Hakları Komiseri vb) ve sivil toplum örgütlerine de gönderilerek görüşleri istenmiştir.

Raporda öneriler üç grupta toplanmıştır; ulusal düzeyde insan hakkı ihlallerinin önlenmesi ve ulusal çözüm mekanizmalarının geliştirilmesi, başvuruları eleme ve inceleme usullerinin optimum hale getirilmesi ve Mahkeme kararlarının yerine getirilmesinin geliştirilmesi ve hızlandırılması. Bakanlar Komitesi bu raporu dikkate alarak Kasım 2002 deki 111'inci toplantısında Mayıs 2003'te belirlenen bu üç husustaki somut önerileri incelemeye karar vermiştir. Yönlendirme Komitesi gelen görüş ve eleştirileri de dikkate alarak hazırladığı ve somut önerilerini detaylandırdığ 1 Nihai Faaliyet Raporunu ${ }^{14} 8$ Nisan 2003 tarihinde Bakanlar Komitesine sunmuştur. 14-15 Mayıs 2003 tarihindeki 112'inci toplantısinda kabul edilen bildirge ${ }^{15}$ ile Bakanlar Komitesi, Yönlendirme Komitesinin görüşlerini paylaştığını belirterek ve bu çerçevede Tavsiye Taslaklarının ve Sözleşmeyi değiştiren Protokol taslak metninin 2004'teki 114'üncü toplantısına kadar hazırlanmas1 konusunda Bakanlar Komitesi Yardımcılarını görevlendirmiştir. Bu bildirge

\footnotetext{
${ }^{12}$ Council of Europe, Committee of Ministers, Decleration on the protection of Human Rights in Europe -Guaranteeing the long-term effectiveness of the European Court of Human Rights, 8 November 2001

${ }^{13}$ Steering Committee for Human Rights $(\mathrm{CDDH})$, Interim Report of the CDDH to the Committee of Ministers 'Guaranteeing the long-term effectiveness of the European Court of Human Rights', (CM(2002)146), 18 October 2002

${ }^{14}$ Steering Committee for Human Rights (CDDH), Final Report containing proposals of the $\mathrm{CDDH}$ 'Guaranteeing the long-term effectiveness of the European Court of Human Rights', (CM(2003)55), 8 April 2003

${ }^{15}$ Council of Europe, Committee of Ministers, Decleration Guaranteeing the long-term effectiveness of the European Court of Human Rights, 15 May 2003
} 
çerçevesinde Yönlendirme Komitesine 14. Protokolün ve Açılayıcı Raporunun hazırlanmasınn yanısıra bir taslak bildirge, üç tavsiye taslağı ve bir de karar taslağı hazırlama görevi verilmiştir. Bunları yaparken ilgili kuruluşlar ve sivil toplum örgütlerinin de görüşlerine başvurulması istenmiştir. Yönlendirme Komitesi Kasım 2003'te gönderdiği Faaliyet Raporunun ${ }^{16}$ ardından Nisan 2004'te Protokol taslağını da içeren Nihai Faaliyet Raporunu ${ }^{17}$ Bakanlar Komitesine ulaştırmıştır. Bakanlar Komitesinin 12-13 Mayıs 2004 tarihindeki 114'üncü toplantısında 14. Protokol imzaya açılmış ve toplantı sonunda 'Avrupa İnsan Hakları Sözleşmesinin Ulusal ve Avrupa Düzeyinde Etkin Uygulamasının Sağlanması ${ }^{18}$ başlığı ile yayınlanan bildirge ile taraf devletler reform ihtiyacının aciliyetini kabul ederek 14. Protokolü iki yıl içinde onaylamayı taahhüt etmişlerdir.

Görüldüğg̈ gibi Protokol uzun ve profesyonel bir çalışma sonucunda demokratik katılıma olanak sağlayarak hazırlanmıştır. Bu hazırlık sürecinde pek çok farklı öneriler dile getirilmiş ancak bunlardan sadece bazıları Protokolde yer almıştır. Protokolün hazırlanması sürecinde denetim mekanizmasının ikincil niteliğini bozacak veya yargısal niteliğini zayıflatacak ya da bireysel başvuru hakkının kullanılmasını zorlaştıracak değişikliklerden özellikle kaçınılmıştır. Tüm hazırlık sürecinde Mahkemenin gelecekteki fonksiyonunun ne olacağı ya da olması gerektiği yönünde iki farklı yaklaşımın ortaya çıktığı gözlemlenmektedir. Bunlardan birisi Mahkemenin insan haklarına ilişkin temel ilke kararlarını alan bir anayasal yarg1 organı gibi hareket etmesi gerektiğini savunurken, diğeri taraf ülkelerdeki hakları ihlal edilen tüm bireylerin kolaylıkla ulaşıp haklarını arayabilecekleri bir organ olması gerektiğini ileri sürmüşlerdir. ${ }^{99}$ Getirilen değişikliklerin bu görüşlerden yalnızca birini kabul eden bir yaklaşımdan ziyade iki yaklaşım arasında bir pozisyonun benimsenmesinin ürünü olduğu görülebilir. Aşağıda getirilen değişiklikler incelenirken yer yer reddedilen önerilere de değinilecektir.

\footnotetext{
${ }^{16} \mathrm{CM}(2003) 165$, Addendum I

${ }^{17}$ Steering Committee for Human Rights (CDDH), Final Activity Report of the CDDH to the Committee of Ministers 'Guaranteeing the long-term effectiveness of the European Court of Human Rights', (CM(2004)65), 8 April 2004

${ }^{18}$ Council of Europe, Committee of Ministers, Decleration Ensuring the effectiveness of the implementation of the European Convention on Human Rights at national and European levels, 13 May 2004-09-13

${ }^{19}$ Dembour, Marie-Benedicte 'Finishing off Cases: The Radical Solution to the Problem of the Expanding ECTHR Caseload' European Human Rights Law Review (2002), 5, 604-23
} 


\section{Mahkemenin İsyükü̈nün Niteliği}

Yukarıda detayları açıklanan hazırlık çalışmaları sırasında Avrupa İnsan Hakları Mahkemesinin karşılaştı̆̆ işyükü probleminin doğasına ilişkin tespitler yapılmaya çalışılmıştır. Bu çerçevede yapılan başvuruların niteliği, inceleme sürecinin gecikmesine neden olan çalışma yöntemleri, inceleme sürecinin hangi aşamalarında geçikmelerin yaşandığ 1 ve gecikmelerin nedenleri ortaya konulmuştur.

Burada kısaca hem Mahkemenin başvuruları inceleme yöntemi hem de başvuruların niteliği hakkındaki temel bulgulara değinilecektir. Buna göre Mahkemeye yaklaşık olarak günlük ortalama 800 mektup ulaşmaktadır. ${ }^{20}$ Mahkemenin yakın zamana kadar uyguladığı usule göre gelen mektuplar hemen başvuru olarak kabul edilmemekte, bunlar için önce geçici bir dosya açılmakta ve Mahkeme kalemi başvurucuya bir resmi başvuru formu ile başvurunun akibetine ilișkin muhtemel gelişmeler hakkında temel bilgiler göndermektedir. Bundan sonra başvurucu başvurusuna devam etmek için gerekli belgeleri gönderirse başvuru kaydedilmektedir. $\mathrm{Bu}$ aşamada başvurucuların önemli bir kısmı başvurmaktan vazgeçmektedir. Bazı istatistiki verilere bakılırsa yıllara göre açılan geçici dosya (GD) ve kaydedilen başvuru (KB) sayıları şöyledir: yıl 1988, GD 4044, KB 1013; yıl 1999, GD 20 538, KB 8402; y1l 2000, GD 26 398, KB10 486. ${ }^{21}$ Yani yaklaşık olarak geçici dosya açılan başvuruların ancak üçte biri başvuru olarak kaydedilmektedir. Ancak bu geçici dosya açma yönteminin incelemeyi uzattığı tespit edilerek yukarıda anlatılan çalışmalar sonucunda bu yöntemden vazgeçilmiştir.

Farklı taraf devletler aleyhine yapılan başvuru sayılarında önemli farklılıklar vardır. Mesela 2000 yılında bazı ülkeler aleyhine kaydedilen başvuru sayıları şöyledir; Arnavutluk 3, Almanya 592, Belçika 73, Bulgaristan 304, Çek Cumhuriyeti 198, Danimarka 56, Estonya 46, Fransa 1032, Hollanda 173, İtalya 866, İrlanda 18, Kıbris 17, Polonya 776, Romanya 640, Rusya 1324, Ukrayna 727, Türkiye 734, Yunanistan 124. Bu sayılar yıllara göre bazı farklılıklar da göstermektedir. Aynı ülkeler aleyhine 2003 yılında yapılan başvuru sayıları ise şu şekildedir; Arnavutluk 24, Almanya 1911, Belçika 215, Bulgaristan 702, Çek Cumhuriyeti 943, Danimarka 142, Estonya 179, Fransa 2906, Hollanda 451, İtalya 1845, İrlanda 76, Kıbris 44, Polonya 5359, Romanya 4195, Rusya 5996, Ukrayna 2276, Türkiye 2918, Yunanistan $481 .^{22} \mathrm{Bu}$ başvuru sayılarının ülkelerin nüfuslarına oranlarında da önemli farklılıklar bulunmaktadır. Mesela 2000 yılı rakamlarına göre başvuruların nüfusa oranı Arnavutluk ve Gürcistan gibi yeni taraf olan ülkelerde sirasıyla $0.9 / 1000,000$ ve $1.4 / 1000,000$ gibi çok

\footnotetext{
${ }^{20}$ EG Court(2001)1, §22

${ }^{21}$ Ibid, $\$ 25$

${ }^{22}$ Survey of Activities 2003, (Rakamlardaki artışta başvuruları kayıt sisteminde yapılan değişikliğinde etkisi dikkate alınmalıdır)
} 
düşük olduğu, buna karşılık 1990'larda taraf olan Slovakya (52.6/1000,000), Litvanya $(50.8 / 1000,000)$ ve Estonya $(32.9 / 1000,000)$ gibi ülkelerde ise daha yüksektir. Tüm Konsey üyesi ülkeler ortalamas1 14/1000,000 dür. Bir önceki yıla göre toplam ortalamada artış gözlemlenmiştir (1999 yılı ortalaması $11 / 1000,000)^{23}$

Başvuruların niteliğine ilişkin olarak da ilginç veriler bulunmaktadır. Başvuruların pek çoğu benzer nitelikli (clone) şikayetler içermektedir. En fazla başvuru konusu olan yargılamanın makul sürede yapılmamış olmasıdır. 1955-1999 yılları arasında verilen toplam 5307 kabul edilebilirlik kararından 3129'u yargılamanın makul sürede yapılmadığı şikayetini içermektedir. Ve bu başvuruların çoğunluğu İtalya aleyhine yapılmıştır. Mesela 2000 yılında verilen 1085 kabul edilebilirlik kararından 486's İtalya aleyhine idi ve bunlardan 428'i yargılamanın makul sürede olmadığı şikayetini içermektedir. ${ }^{24}$ Mahkemeyi meşgul eden başvurulardan pek çoğu daha önce detaylı olarak inceleyip hüküm verdiği başvurulara benzemektedir. Makul süre davalarının yanı sıra, mesela İtalya aleyhine yapılan tahliye kararlarının uygulanması için polis yardımı yapılmaması, ${ }^{25}$ Türkiye aleyhine yapılan kamulaştırma bedellerinin enflasyon nedeniyle değerini kaybettiğine ilişkin başvurular ${ }^{26}$ ya da Kıbrıs başvuruları, ${ }^{27}$ orta ve doğu Avrupa ülkelerinde komünist dönemde bedelsiz kamulaştırılan malların demokrasiye geçiş sonrası dönemde geri verilmesine ilişkin yasaların uygulanmasından doğan başvurular ${ }^{28}$ başlıca örnekler olarak verilebilir. Bu şekildeki başvurular bir taraftan Mahkeme kararlarının taraf devletler tarafindan etkin bir şekilde uygulanamadığını göstermektedir. $\mathrm{Bu}$ nedenle yapilacak reformun Mahkeme kararlarına uyma konusunda devletleri cesaretlendirici boyutlar içermesi gerekmektedir. Diğer taraftan bu tür başvuruların tamamen ortadan kaldırılamayacağı dikkate alınarak Mahkemenin Sözleşmenin yorumu bakımından bir özellik arzetmeyen rutin başvuruları daha basit bir yöntemle sonuçlandırmasına imkan verecek düzenlemeler bu reformda yer almalıdır.

Yukarıda geçici dosya açılan başvuruların ancak 1/3'ünün kayıtlı başvuru haline geldiği belirtilmişti. Kaydedilen başvurularında çok azı Mahkeme tarafindan esastan incelenmektedir. Mesela 2000 yilinda Mahkeme tarafindan incelemesi sonuçlandırılan toplam 7711 kayıtlı

${ }^{23} \mathrm{Ibid}, \S 26$

${ }^{24} \mathrm{Ibid}, \$ 27$

25 Immobiliare Saffi/Ittalya, 28 Temmuz 1999; A.O./Ittalya, 30 Mayıs 2000 (burada verilen kararlar bu konuda verilen ilk kararlardır, daha sonra aynı içerikli pek çok karar çıkmıştır).

${ }^{26}$ Akkuş/Türkiye, 09 Temmuz 1997, Reports 1997-4; Aka/Türkiye 23 Ağustos 1998, Reports 1998-VI (ilke kararlar).

27 Loizidou/Türkiye, 18.12.1996, Reports 1996-VI; Klbrı/sürkiye, 10.05.2001; Baş. No.25781/94

${ }_{28}^{28}$ Brumerascu/Romanya, 28.11.1999, Baş.No.28342/95; Vasiliu/Romanya, 21 Mayıs 2002, Baş. No. 29407/96 
başvurudan 6774'ü (\% 88) kabul edilemezlik ya da Mahkeme listesinden çıkarma kararı, 227'si dostane çözüm, 695'i esas hakkında verilen karar (toplam sonuçlandırılan başvuruların \%9'u) ve 15'i de diğer şekillerde sona ermiştir. ${ }^{29} \mathrm{Bu}$ rakamlar bize Mahkemenin önüne gelen başvuruların önemli bir kısmının esastan incelenemeyecek başvurulardan oluştuğunu göstermektedir. O nedenle de yapılacak reform ile başvuruların başlangıçta etkin bir şekilde elenmesine imkan verecek bir çözümün bulunması gerekmektedir.

Kaydedilen bir başvurunun Mahkeme tarafindan incelenmesi süreci üç ya da dört aşamada tamamlanmaktadır. Kısaca bu aşamalara göz atmak gerekirse, ilk aşamaya ilk inceleme aşaması denilebilir. Başvuru kaydedilince Mahkemenin dört bölümünden (section) birisine gönderilir. Bölüm başkanı başvuruyu incelemek üzere bir raportör yargıç atar. Raportör yargıç yazı işlerinden başvuru için görevlendirilen davayı yürüten memurla işbirliği içinde ilk incelemesini tamamlar. İlk incelemenin amacı başvurunun kabul edilebilirlik için incelenmesi ve hazırlanmasıdır. Raportör yargıç gerekirse başvuru ile ilgili her türlü belge ve bilgileri taraflardan isteyebilir. İncelemesini tamamlayan yargıç eğer başvuru konusu karmaşık değilse ve kabul edilemez görünüyorsa dosyayı kendi görüşü ile birlikte üç yargıçtan oluşan Komiteye gönderir. Komite başvurunun kabul edilemezliğine oy birliği ile karar verebilir ve bu karar kesindir. Bu karar ilave bir inceleme yapılmaksızın alınır ve uygulamada yukarıda belirtildiği gibi başvuruların büyük bir bölümü bu şekilde sonuçlanmaktadır. Eğer Komite oy birliği sağlayamazsa dosya yedi yargıçtan oluşan Daireye gönderilir. Aynı şekilde raportör dosyanın daha detaylı incelenmesi gerektiğini düşünüyorsa şikayet konusu olayın özetini ve yapılması gereken işlemleri içeren raporuyla birlikte dosyayı Daireye gönderir.

İkinci aşama bundan sonra başlar. Buna ikinci inceleme aşaması denilebilir. Daire başlangıçta başvurunun kabul edilemez olduğuna karar vermezse davalı devletten başvuruya ilişkin görüşlerini ister ve başvurucuya da cevap hakkı tanır. Bundan sonra gerekirse Daire duruşma yapmaya karar verebilir. Duruşmada hem kabul edilebirliğe hem de esasa ilişkin hususlar üzerinde durulabilir. Daire bundan sonra başvurunun kabul edilebilirliğine ilişkin kararını verecektir. Eğer Daire başvuruyu kabul edilemez bulursa bu karar kesindir. Kabul edilemezlik kararının taslağını hazırlamak da raportörün görevidir. Eğer başvuru Sözleşmenin yorumunu gerektiren önemli bir husus içeriyorsa ya da Dairenin vereceği kararın Mahkemenin daha önce verdiği kararlardan farklılaşması ihtimali varsa ve taraflar itiraz etmezlerse Daire incelemenin her aşamasında onyedi yargıçtan oluşan Büyük Daire lehine dosyadan feragatta bulunabilir.

\footnotetext{
${ }^{29}$ EG Court (2001)1, §28
} 
Kabul edilebilirlik kararından sonraki üçüncü aşamada başvuru esastan incelenir. Bu aşamada öncelikle Mahkemenin yazı işleri müdürü (Registrar) dostane çözüm arayışlarına girer ve gizli olarak bu görüşmeleri yürütür. Görüşmelerden bir sonuç çıkmazsa Daire başvuruyu esastan inceleyerek kararını verir. İncelemeler sırasında taraflardan yazılı ve gerekirse sözlü görüşleri alınır. İnceleme sonucu raportör yargıç davalı devlet adına seçilen yargıcın da yardımıyla karar taslağını hazırlar ve bu taslak Dairede oylanır. Daire kararları oy çokluğuyla alınabilir ve karşı oylar da karara eklenir. Dairenin esasa ilişkin kararları kesin değildir ve üç aylık sürede taraflar dosyanın Büyük Daire tarafindan yeniden incelenmesini isteyebilirler. Eğer böyle bir başvuru olursa dördüncü aşama başlar. Yeniden inceleme talebi önce beş yargıçtan oluşan bir kurul tarafından incelenir. Burada başvurunun Sözleşmenin yorumunu gerektiren önemli bir husus içerip içermediği ya da önemli bir durumun varlığı dikkate alınır. Kurul yeniden inceleme kararı verirse başvuru onyedi yargıçlı Büyük Daire tarafindan incelenir ve karar oy çokluğuyla alınabilir. Büyük Daire kararları kesindir. ${ }^{30}$

Mahkeme ideal olarak bu sürecin yani bir başvurunun kaydedilme tarihinden itibaren en geç iki yıl içinde sonuçlanmasını amaçlamaktadır. ${ }^{31}$ Ancak mevcut işyükü altında bunu gerçekleştirmenin imkansız olduğunu gören Mahkeme geçici bir süre yukarıdaki aşamaların her biri için 12 ay olmak üzere bir başvurunun kayıttan iribaren en geç üç yılda sonuçlandırılmasını amaçlamaktadır. Bu sürelerin aşılmasının Mahkemenin etkinliğini zayıflatacağı düşünülmektedir. Kabaca başvuruların yaklaşık yarısı kayıt tarihinden itibaren bir yıl içinde sonuçlandırılmaktadır. Ancak önemli sayıda başvuru da hedeflenen üç yıllık sürede sonuçlanamamaktadır. Mesela 2001 yılı Eylül ayında Mahkemenin önünde derdest olan toplam 19200 başvurudan 2250'si üç yıldan daha fazla süredir Mahkemenin önünde bulunuyordu. Bazı başvuruların 6 yılda bile sonuçlandırılamadığ görülmektedir. Mesela 1997 y1lında kaydedilen toplam 4719 başvurudan 514'ü dört yıl sonunda hala sonuçlanmamıştır. ${ }^{32}$ Mahkemenin esas hakkında verdiği kararlar hukuki önemi açısından da incelemeye tabi tutulmuştur. Buna göre kararlar önemleri bakımından dörde ayrılmıştır. 1) Mahkemenin karar ve hükümler dergisinde yayınlanması uygun görülen öncü kararlar, 2) yeni sorunlara ilişkin olan fakat yayınlanacak kadar önemli olmayan kararlar, 3) Mahkemenin yerleşmiş içtihadının uygulandığı standart kararlar, 4) yargılama süresinin makul olmadığı iddiasına dayanan standart kararlar. Bunlardan esaslı incelemeyi gerektirenler ilk iki kategori kararlardır, son iki kategori kararda tartışılacak yeni bir durum olmadığından Mahkemenin yerleşik içtihadının uygulanması sözkonusudur. Mahkemenin 2002 yılında vermiş olduğu esasa ilișkin toplam 695 karardan 94'ü 1., 35'i 2., 81'i 3. ve

\footnotetext{
${ }^{30}$ EG Court (2001)1, §28

${ }^{31} \mathrm{Ibid}, \S 31$

${ }^{32}$ Ibid
} 
485'inin 4. kategoriye girdiği görülmektedir. ${ }^{33} \mathrm{Bu}$ da kararların önemli bir bölümünün Sözleşmenin ciddi yorumunu gerektirmeyen basit başvurular hakkında olduğu ve bu tür başvurular için daha basit bir inceleme yönteminin bulunmasının mümkün olduğunu göstermektedir.

Bir kısmını burada aktardığımız bulgular ışığında yürütülen çalışmalar sonucu ortaya çıkan 14. Protokol temelde burada ortaya konan sorunlara çözüm getirmeyi amaçlamaktadır.

\section{14. Protokolün Getirdiği Değişiklikler}

11. Protokolün aksine 14. Protokol Sözleşmenin kontrol mekanizmasında radikal değișiklikler öngörmemektedir. Kontrol mekanizmasında yapılan değişiklikler yapısal olmaktan çok fonksiyonel değișikliklerdir. Protokolle Mahkemeye usulü bazı yetki ve esneklikler tanınması yoluyla Mahkemenin tüm başvuruları zamanında sonuçlandırması ve detaylı inceleme gerektiren önemli olaylara yeterli zaman ayırabilmesine olanak tanınması amaçlanmıştır. Bunu sağlamak için üç alanda değişiklik yapılmaktadır: a) Başvuruların önemli bölümünü olușturan kabul edilemez şikayetleri eleme konusunda Mahkemenin yetkileri artmaktadır, b) Mahkemeye başvurucuların önemli bir zarara uğramadığı önemsiz başvuruları reddetme imkanı veren yeni bir kabul edilemezlik şartı ihdas edilmektedir ve c) bir birine benzer, tekrar niteliğindeki başvurulara ilişkin yeni tedbirler öngörülmektedir. Bu değişikliklerin Mahkemenin kabul edilemez ve birbirine benzeyen davalara harcadığı zamanı azaltarak insan hakları alanında önemli sorunlar içeren davalara daha fazla zaman ayırmasına imkan vereceği hesaplanmaktadır. ${ }^{34}$

Mahkemenin eleme kapasitesi tek yargıç tarafından bireysel başvurularda kabul edilemezlik ya da listeden çıkarma kararı verilmesi yetkisinin tanınması yoluyla artırılmıştır. Böylece hem kabul edilemezlik kararlarının yargısal niteliği korunmuş, hem de Mahkemenin karar alma kapasitesi artırılmıştır. Burada tek yargıca yazı işlerinin personeli olan hukukçu raportörler yardımcı olacaktır.

Yeni kabul edilebilirlik şartı Mahkemeye bireylerin önemli bir zarara uğramadı ̆̆ı önemsiz başvuruları reddetme imkanı vermektedir. Ancak Sözleşme ve Protokollerinde tanınan insan haklarına saygı ilkesi başvurunun esastan incelenmesini gerektiriyorsa ya da başvuru konusu olay milli bir Mahkeme tarafından etraflı bir şekilde incelenmemișse bu nedene dayanarak kabul edilemezlik kararı verilemeyecektir. Yeni kabul edilebilirlik şartı tüm reform süreci boyunca Mahkemenin fonksiyonun ne olması gerektiği konusunda çarpışan iki farklı görüşü uzlaştırır şekilde düzenlenmiştir. Yani,

${ }^{33}$ İbid, $\$ 32$

${ }^{34} \mathrm{ER}, \S 8$ 
yeni kabul edilebilirlik şartı bir taraftan Mahkemenin dikkatini insan hakları konusunda ilkesel kararlar alınması gereken önemli olaylara teksif etmesine imkan verirken, diğer taraftan bireysel başvuru hakkını daraltmamasına özen gösterilmiştir. Bu husus aşağıda biraz daha detaylı incelenecektir.

Protokolle Sözleşmenin yorumunu gerektirmeyen ve daha önce Mahkeme tarafindan incelenerek ilke kararı verilmiş olaylara benzer ya da tekrar nitelikteki başvurularda incelemenin daha hızlı sonuçlandırılabilmesi için üç kişilik Komiteye bu tür başvularda esas hakkında karar verme yetkisi tanınmaktadır. Elbette bu tür başvurulara ilişkin tek yenilik Komiteye esas hakkında karar verme yetkisi tanınması değildir. Bundan başka Mahkeme Kararlarının uygulanmasını zorlayıcı tedbirlerle bu tür başvuruların azaltılmasını amaçlamaktadır. $\mathrm{Bu}$ konuda Protokolün getirdiği yenilikle Bakanlar Komitesine, kendisine süre verilmesine rağmen Mahkeme kararlarını uygulamamakta direnen taraf devletler aleyhine 2/3 çoğunlukla Büyük Daireye başvurma hakkı tanınmaktadır. Bu başvurunun amacı taraf devletin Sözleşmenin 46/1. maddesinden doğan yükümlülüğünü ihlal ettiği yolunda bir karar verilmesini temin etmektir.

$\mathrm{Bu}$ temel değişikliklerden başka kabul edilebilirlik ve esas hakkındaki kararların birlikte verilmesinin teşvik edilmesi, dostane çözümün teşvik edilmesi ve verilen dostane çözüm kararlarının uygulanmasının gözetiminin de Bakanlar Komitesine verilmesi, yargıçların dokuz yıllık tek bir dönem için seçilmesi ve Avrupa Birliğinin de Sözleşmeye taraf olmasına imkan veren bir hükmün Sözleşmeye eklenmesi 14. Protokolün getirdiği yeniliklerdir.

Şimdi Protokolü daha yakından incelemek gerekirse, Protokol 22 maddeden oluşmaktadır. Protokolün 1. maddesi Sözleşmenin 22. maddesinin 2 parağrafının silindiği hükmünü içermektedir. Yargıçların seçim yöntemini düzenleyen bu maddenin ikinci parağrafi Sözleşmeye yeni bir devletin taraf olması ya da Mahkeme üyeliklerinde geçici boşalma olması halinde de aynı seçim yönteminin uygulanacağı hükmünü içeriyordu. Protokol yargıçların seçim yönteminde herhangi bir değişiklik yapmazken bu hükmün gereksiz olduğu düşüncesiyle Sözleşme metninden çıkarılmasını amaçlamıştır.

2. madde yargıçların görev süresini düzenleyen 23. maddede değişiklik yapmaktadır. Yargıçların görev süresi altı yıldan dokuz yıla çıkarılmakta ve yeniden seçilme imkanı ortadan kaldırılmaktadır. Bunun yanında 70 yaşında emekli olma hükmü korunmakta ve mevcut 24. maddede düzenlenen yargıcın görevden alınmasına ilişkin hüküm 23. maddeye bir fikra olarak girmektedir. Bu değişiklik Değerlendirme Grubu ve Parlamenterler Meclisi tarafından önerilmiş ve Yönlendirme Komitesi tarafından benimsenerek Protokole girmiştir. Değişiklikle yargıçların tekrar seçilme kaygısından kurtarılarak tarafsızlıklarının ve bağımsızlıklarının güçlendirilmesi amaçlanmaktadır. Elbette yargıçların bağımsızlı̆̆ 1 sadece yeniden seçilmelerinin engellenmesi ile sağlanamaz, bağımsızlığın sağlanmasında 
aday gösterme ve seçme yönteminin de büyük etkisi vardır. ${ }^{35}$ Ancak bu konudaki Bakanlar Komitesi ve Parlamenterler Meclisinin yaptığ çalışmalar dikkate alınarak yargıçların seçim sisteminde herhangi bir değişiklik Protokolde yer almamıştır. Yargıçlık süresinin altı yıldan dokuz yıla çıkarılmasının amacı ise Mahkemede ve içtihatlarda devamlılı̆̆ın sağlanmasıdır. Yargıçlık süresi ve devamlılığın sağlanmasına yönelik değișik teklifler (sürenin 10 y1l olması ve her 2,5 y1lda dörtte birinin değişmesi, sürenin 12 yıl yapılarak 3 yılda bir dörtte birinin değişmesi, 9 yıl yapılarak 3 yılda bir üçte birinin değişmesi vb) değerlendirilerek dokuz yılda karar kılınmıştır. Böylece seçilen her yargıç dokuz yıllık bir süre için göreve gelecek ve zamanla her yargıcın göreve başlama süreleri bir birinden farklılaşarak devamlılık kendiliğinden sağlanmış olacaktır. ${ }^{36}$ Emeklilik yaşı olarak 70 yaş sınırı korunmuş ancak adaylık için yeni bir yaş sınırı konulmamıştır.

Hazırlık çalışmaları sırasında Mahkemenin yapısına ilişkin pek çok öneri getirilmiştir. Mesela bazı bölgesel Mahkemelerin kurulması, başvuru sayısı çok olan ülkelerden birden fazla yargıç seçilmesi ve bu konuda Bakanlar Komitesine ya da Mahkemeye yetki verilmesi, Başvuruların ilk incelemesini yapacak yeni bir organın oluşturulması gibi öneriler yapılmış fakat kabul görmemiştir. Bölgesel Mahkeme kurulması önerisinin reddedilme nedenleri arasında Mahkeme ve içtihat bütünlüğünün korunmasını zorlaştırması, Avrupalı olma niteliğini zayıflatması ve maliyetleri artırması gibi sebepler bulunmaktadır. ${ }^{37}$ Başvuru sayısı çok olan ülkelerden birden fazla yargıç seçilmesinin Mahkeme bütünlüğünü bozacağg ve Sözleşmeye taraf ülkelerin eşit temsili ilkesiyle çelişeceği düşünülmüştür. ${ }^{38}$ İlk incelemeyi yapacak yeni bir organ kurulması ise hem kontrol mekanizmasının yargısal niteliğini bozacağı hem de başvuruların sonuçlandırılma süresini kısaltmak yerine uzatma ihtimali hem de 11 . Protokol öncesine dönüş anlamına geleceğinden uygun bulunmamıştır. ${ }^{39}$

3. madde Sözleşmenin 24. maddesinin içeriğinin bir fikra halinde 23. maddeye alınması nedeniyle bu maddenin silinmesi hükmünü içermektedir.

4. madde Sözleşmenin eski 25. maddesini 24. madde olarak yeniden düzenlemektedir. Burada Mahkemenin yazı işleri ve raportörler düzenleme konusudur. 25. maddenin Mahkemeye hukuki sekreterliklerin yardım edeceği hükmünü içeren ikinci cümlesi hiçbir zaman böyle bir hukuki sekreterlik kurulmadığı için silinmekte ve raportörleri düzenleyen yeni ikinci fikra eklenmektedir. Buna göre tek yargıçla karar vereceği zaman Mahkemeye, Mahkeme başkanının emrinde çalışacak raportörler tarafından

${ }^{35} \mathrm{CM}(2002) 146, \S 47$

${ }^{36} \mathrm{ER}, \$ 51$

${ }^{37}$ EG Court(2001)1, §83

${ }^{38} \mathrm{CDDH}(2003) 026$ Addendum I Final, § 41

${ }^{39} \mathrm{CM}(2002) 146, \S 31$ 
yardım edileceği ve raportörlerin yazı işlerinin bir parçası olacağ hükme bağlanmaktadır. Raportörlerin yeni dönemde ifa edecekleri işlevin Mahkemenin eleme kapasitesinin artırılmasındaki rolünün önemine vurgu yapmak için hukuki olarak zorunlu olmamasına rağmen Sözleşme metninde zikredilmeleri istenmiştir. Raportörlerin başvurunun ilgili olduğu ülkenin dili ve hukuk sistemi hakkında uzman olmaları gerekmektedir ve işlevleri yargıçlarınkinden tamamen farklıdır. Raportörlerin sayısı, görevlendirilmeleri ve görev süreleri konusunda Mahkeme ihtiyaçlara göre kendisi karar verecektir.

5. madde Sözleşmenin Mahkeme Genel Kurulunu düzenleyen 26. maddesini yeni 25. madde olarak yeniden düzenlemekte ve yeni bir f fikrasi eklemektedir. Bu fikra Genel Kurula Bakanlar Komitesinden Dairelerdeki yargıç sayısını belli bir süre için beşe düşürmesini talep etme hakkı tanıyan yeni 26/2 maddeye atıf yaparak yeni bir yetki tanımaktadır.

6. madde Mahkemenin iç yapısını düzenleyen Sözleşmenin 27. maddesini yeni 26. madde olarak yeniden düzenlemektedir. Madde başlığına 'Tek Yargıç Yapılanması' (single judge formation) ibaresi eklenmektedir. Böylece eski Komite, Daire, ve Büyük Daire şeklindeki yapılanmaya dördüncü bir organ eklenmektedir. Maddenin birinci paragrafi da tek yargıç yapılanmasını içerir şekilde yeniden düzenlenmektedir. 2. paragrafta yukarıda belirtildiği gibi Mahkeme Genel Kuruluna Bakanlar Komitesinden belli süreler için Dairelerdeki yargıç sayısını beşe düşürmesini talep etme yetkisi tanınmaktadır. 3. paragraf ise tek yargıç formunda yargıçların kendi seçildikleri ülke aleyhine yapılan başvurularda tek yargıç olarak görev yapamayacağ hükmünü içermektedir. 4. paragraf eski 27/2 maddedeki ad hoc yargıç atama prosedürünü değiştirerek düzenlemektedir. Buna göre Daire ve Büyük Dairede başvurunun ilgili olduğu devlet yargıcı doğal üye olarak görev alacaktır ancak bu yargıç müsait değilse (bir hukuki engel nedeniyle) o devletin daha önceden belirlediği listeden Mahkeme başkanı bir ad hoc yargıç atayacaktır. Eski sistemde ise ad hoc yargıç ihtiyacı ortaya çıktıktan sonra ilgili devlet ad hoc yargıcı belirliyor ve o yargıç görev yapıyordu bu usul ise eleştiriliyordu. ${ }^{40}$ Yeni değişiklikle ad hoc yargıçlar önceden belirlenecek ve Mahkeme Başkanı bunlardan birisini göreve çağıracaktır.

Tek yargıç yapılanmasının Mahkemenin başvuruları eleme kapasitesini önemli ölçüde artıracağı öngörülebilir. Çünkü üç yargıç yerine tek yargıç kabul edilemezlik kararlarını vermeye yetkili olacak ve bu yargıç raportörlük görevlerinden sıyrılmış olarak çalışacaktır. Tek yargıca yazı işlerinin bir elemanı olan hukukçu raportörler yardımcı olacaktır. Diğer taraftan 2. paragraf ile Dairelerin Yargıç sayısını belirlemede Mahkemeye bir esneklik tanınmaktadır. Ancak bu aynı anda değişik başvurular için değişik sayıda

${ }^{40} \mathrm{CDDH}(2003) 026$ Addendum I Final, $§ 26$ 
dairelerin bulunabileceği anlamına gelmemelidir. Dairelerdeki yargıç sayısının yediden beşe düşürülmesi de Mahkemenin hızlı karar verme kapasitesini artıracak ve daha fazla daire oluşturarak daha fazla davaya bakma olanağı sağlayacaktır.

7. madde tek yargıç yapılanmasının yetkilerini düzenleyen yeni bir 27 . madde getirmektedir. Buna göre 34. maddeye göre yapılan bireysel başvurular eğer detaylı bir incelemeye gerek olmadan reddedilebilir nitelikte ise tek yargıç tarafından kabul edilemezlik kararı verilebilir ya da Mahkemenin dava listesinden çıkarılmasına karar verilebilir. Bu kararlar kesindir. Eğer tek yargıç başvuruyu kabul edilemez bulmaz ya da dava listesinden çıkarılmasına karar vermezse başvuruyu detaylı inceleme için Komiteye ya da Daireye gönderir. Tek yargıca tanınan kabul edilemezlik kararı verme yetkisi sadece ilk bakışta açıkça kabul edilemez olan başvurular için söz konusu olacaktır. Ancak bu yetkinin hangi kabul edilemezlik şartları için kullanılacağının belirlenmesinde zorluklar ortaya çıkabilir. Başvurunun imzasız olması ya da altı aylık süre koşuluna uyulmaması gibi koşulların uygulanması nispeten daha kolay olacaktır. Ancak mağdur sıfatını taşımak, iç hukuk yollarını tüketmek gibi koşulların yorumlanması gerekebilir ve bu yorumlamayı tek yargıcın yapıp yapamayacağı tartışma konusu olabilir. Özellikle 35. maddeye yeni getirilen kabul edilebilirlik şartının tek yargıç tarafindan uygulanması geniş tartışmalara neden olabilir. Her ne kadar bu şartın Protokolün 20. maddesi ile geçiş döneminde iki yıl boyunca sadece Daireler ve Büyük Daire tarafından uygulanabileceği hükmü getirilmişse de daha sonra tek yargıç tarafından uygulanmasında değişik tartışmalara yol açma potansiyelini barındırmaktadır.

O nedenle tek yargıç bir başvuruyu ancak çok açık şekilde şartları taşımıyorsa kabul edilemezlik kararı vermelidir. Küçük bir şüphe halinde Komite ya da Daireye göndermelidir. Aksi takdirde tek yargıcın kararı kesin olarak başvuruyu Mahkeme gündeminden düşüreceğinden bu değişiklik bireylerin Mahkemeye başvuru hakkını zayıflatan bir işlev görebilir. Özellikle kabul edilebilirlik koşullarına ilişkin detaylı inceleme gerektiren ya da içtihat değişikliği gerektiren hususlarda tek yargıç kabul edilemezlik kararı vermekten özenle kaçınmalıdır. Mahkemenin iş yükü yargıçlar için birincil öncelik haline gelirse insan haklarına ilişkin önemli problemlere Mahkemenin yeterince dikkat göstermemesi sonucunu doğurabilir ve bu da Mahkemenin saygınlığını azaltan bir sonuç doğurabilir.

Protokolün 8. maddesi Komitelerin yetkilerini düzenleyen 28. maddede bazı değişiklikler yapmaktadır. Buna göre Komite bir başvuruyu detaylı incelemeye gerek olmadan kabul edilemez görürse kabul edilemezlik ya da dava listesinden çıkarma kararı verebilir. Ya da kabul edilebilirlik kararı verebilir ve eğer başvuruda söz konusu olan uyuşmazlık Mahkemenin daha önceden inceleyerek Sözleşmeyi yorumlayıp uyguladığ1 ve yerleşik içtihat oluşturduğu bir hususa ilişkinse esas hakkında da karar verebilir. Bu kararlar 
kesindir. Başvuru hangi devlet aleyhine yapılmışsa o devlet adına seçilen yargıç Komitenin üyesi değilse, Komite incelemelerin her aşamasında bu yargıcı Komiteye davet ederek yargıçlardan birisinin yerini almasını isteyebilir.

$\mathrm{Bu}$ madde ile önemli bir yenilik yapılarak üç kişilik Komiteye bazı başvuruların esası hakkında karar verme yetkisi tanınmaktadır. Bu yetki esas olarak Mahkemenin iş yükünün önemli bir bölümünü (2003 yılında verilen kararların yaklaşık \%60'1) oluşturan tekrar ya da benzer nitelikteki başvuruların daha kolay sonuçlandırılmasını amaçlamaktadır. ${ }^{41}$ Benzer nitelikteki başvurularda karar alma bu değişiklikle bir taraftan hem basitleştirilmiş hem de hızlandırılmış, diğer taraftan da sistemin çekişmeli ve kararların yargısal olma niteliği korunmuştur. ${ }^{42}$ Başvuru Komite tarafindan ilgili devletin dikkatine sunularak yerleşik içtihat bulunan bir hususla ilgili olduğu belirtilecektir. Taraf devlet buna katılabilir ya da farklı nedenlerle (iç hukuk yollarının tüketilmediği, yerleşik içtihat olan konudan farklı nitelik taşıdığ $1 \mathrm{vb}$ ) itiraz edebilir. Fakat taraf devletin komitenin karar vermesini engelleme yetkisi bulunmamaktadır. Komite kararları oybirliği ile olmalıdır, oybirliği yoksa Komite karar alamaz. Komitenin oybirliği ile almış olduğu kararlar ise kesindir. Ayrıca ilgili devlet adına seçilen yargıcın Komitenin üyesi olması zorunluluğu yoktur. Komite gerekirse, özellikle ilgili devlet basit usulün uygulanmasına karşı çıkmışsa, ilgili devlet yargıcını davet ederek üyelerinden birisi ile değiştirebilir. Bu husus eleştiri konusu olabilir. Çünkü ilgili devlet yargıcı Daire ve Büyük Dairenin doğal üyesi iken Komitenin doğal üyesi değildir ve Komite esasa ilişkin kesin kararlar alabilecektir. Her ne kadar bu başvurucular açısından bir avantaj gibi görünse de taraf devletlerin kabul etmesinde zorluklar olabilir.

$\mathrm{Bu}$ basit usulün uygulanması için 'yerleşik içtihat' kavramının açıklığa kavuşturulması gerekir. Yerleşik içtihat normal olarak Mahkeme tarafından sürekli aynı şekilde verilen kararlar anlamına gelir. Ancak süreklilik mutlak bir unsur değildir. Bazen tek bir karar da yerleşik içtihat anlamına gelebilir, özellikle Büyük Daire tarafından verilen ilkesel kararların bu özelliği taşıdığı söylenebilir. ${ }^{43}$ Benzer nitelikte pek çok başvuru varsa Mahkeme genellikle bunlardan bir tanesini pilot başvuru olarak ele alıp detaylı olarak incelemekte ve diğer benzer başvurular için pilot bir karar vermektedir. Diğer benzer başvuruları ise o pilot karara göre sonuçlandırmaktadır. $\mathrm{Bu}$ nitelikteki pilot kararlar yerleşik içtihat olarak kabul edilecektir. Komite kararlarının kesin oluşu dikkate alındığında acaba bu bir sorun teşkil eder mi? Taraf devlet adına seçilen yargıcın Komitenin zorunlu üyesi olmaması taraf devletin iddialarının yeterince dikkate alınmayabileceği ihtimalini akla getirebilir. Ancak kanaatimizce Protokol bunun için yeterli tedbirleri almış

${ }^{41} \mathrm{ER}, \$ 69$.

${ }^{42} \mathrm{CM}(2003) 55$, p. 7

${ }^{43}$ ER, §68 
gözükmektedir. Çünkü özellikle taraf devlet bir başvurunun yerleşik içtihadın bulunduğu başvurulardan farklı niteliğe sahip olduğunu ileri sürerse, Komite üyelerinden birisinin yerini almak üzere taraf devlet adına seçilen yargıc1 Komiteye davet edecektir. Komitenin karar alabilmesi için de oy birliği gerektiğinden bu konuda önemli bir sorun çıkmasını beklemek için bir neden yoktur.

Protokolün 9. maddesi Dairelerin yetkilerini düzenleyen 29. maddeyi 27 ve 28. maddelerde yapılan değişiklikler doğrultusunda değiştirmektedir. Buna göre, eğer 27 ve 28. maddelere göre bir karar ya da hüküm verilmemişse, 34. maddeye göre yapılan bireysel başvuruların kabul edilebilirlik ve esası hakkındaki karar Daire tarafından verilecektir. Kabul edilebilirlik kararı ayrıca verilebilir. Devlet başvurularında kabul edilebilirlik kararını Dairenin vermesi ilkesinde bir değişiklik yapılmamış ancak Mahkeme tarafından aksi kararlaştırılmadıkça kabul edilebilirlik kararının ayrı verilmesi ilkesi devletlerarası başvurulara münhasır hale getirilmiştir. Bunun için eski 3. paragraf silinerek bu ilke bir cümle halinde 2. paragrafa eklenmiştir. $\mathrm{Bu}$ maddenin getirdiği temel değişiklik maddenin diğer değişiklikler doğrultusunda redaksiyonun dişında Dairelerin bireysel başvurularda kabul edilebilirlik ve esas hakkındaki kararları birlikte almasının teşvik edilmesi ve genel ilke haline getirilmesidir. $\mathrm{Bu}$ da Dairelerin daha hızlı çalışmasına imkan verecektir.

10. madde Büyük Dairenin yetkilerini düzenleyen 31. maddede değişiklik yaparak yeni bir b fikrası eklemektedir. Burada 46. maddede yapılan değişiklik doğrultusunda Bakanlar Komitesince bir devletin Mahkeme kararlarına uymamakta direndiği ve Sözleşmenin 46/1. maddesindeki yükümünü ihlal ettiğine karar verilmesi taleplerini Büyük Dairenin Karara bağlayacağı belirtilmektedir.

Aynı şekilde 11. madde ile de Mahkemenin yetkisini düzenleyen Sözleşmenin 32. maddesine aşağıda detaylı olarak incelenecek olan 46. maddede yeni getirilen yetkiye atıf yapılmaktadır.

Sözleşmedeki en önemli değişikliklerden birisi Protokolün 12. maddesi ile 35. maddeye ilave edilen yeni kabul edilebilirlik şartıdır. Buna göre 'Mahkeme 34 maddeye göre yapılan bireysel başvuruları, ... başvurucunun önemli bir kayba uğramadığ 1 kanaatine vardığ 1 takdirde, Sözleşme ve Protokollerinde tanımlanan insan haklarına saygı ilkesi başvurunun esastan incelenmesini gerektirmedikçe, kabul edilemez ilan edebilir. Ne var ki yerel bir Mahkeme tarafindan detaylı bir şekilde incelenmemiş hiçbir başvuru bu gerekçe ile reddedilemez.' Bu hükümle Mahkemeye önemsiz başvuruları reddetme imkanı getirilerek eleme kapasitesi önemli ölçüde artırılmıştır. Mahkemenin iş yükünde artma trendinin süreceği öngörüsünden hareketle Protokolle getirilen diğer tedbirlerin yeterli olmayabileceği ihtimaline karş1 Mahkemeye böyle bir yetki tanınmıştır. Ancak bunun için iki garanti öngörülmüştür. Başvuranın uğradığı zarar ne kadar önemsiz olursa olsun, 
eğer insan haklarına saygi ilkesi başvurunun esastan incelenmesini gerektiriyorsa kabul edilemezlik kararı verilemez ve aynı şekilde başvuru konusu olay yerel bir Mahkeme tarafindan etraflı bir şekilde incelenmemişse yine kabul edilemezlik kararı verilemez. İkinci garanti aynı zamanda Sözleşmenin öngördüğü koruma mekanizmasının ikincil (subsidiary) niteliğine de vurgu yapmaktadır. Yani, Sözleşmenin uygulanmasından birincil derecede sorumlu olan taraf devletler ve yerel Mahkemelerdir. Ancak bir olay yerel Mahkeme tarafindan detaylı bir şekilde incelenmemişse, Avrupa düzeyinde Mahkeme tarafindan incelenmelidir. Böylece hiç kimse şikayetini inceletebileceği bir makamdan yoksun kalmamış olacaktır. Hazırlık çalışmaları sırasında Mahkemenin maddi olaylara ilişkin inceleme yapmaması, sadece hukuki inceleme yapması önerilmiştir. Fakat böyle bir değişikliğin en ağır insan hakları ihlallerini Mahkemenin denetimi dışında bırakabileceği düşünülerek şiddetli bir şekilde eleştirilmiş ve kabul edilmemişti. ${ }^{44}$ Böylece çoğunlukla yerel Mahkemeler tarafindan detaylı inceleme yapılmamış olan yargısız infaz, gözaltında kaybolma gibi ağır insan hakları ihlallerine neden olan olayların Mahkeme denetimi dışında kalması engellenmiş olmaktadır.

$\mathrm{Bu}$ hükmün bireysel başvuru hakkını kısmen de olsa daralttığı bir gerçektir. Ne var ki madde metni bu daralmayı minimumda tutacak şekilde formüle edilmeye çalışılmışıtır. Hükmün formüle edilmesinde iki eğilimin etkisi gözlemlenmektedir. Bir taraftan Mahkemenin önemsiz başvurularla zaman kaybetmemesi ve zamanını insan hakları alanındaki önemli ilkesel kararların alınmasına hasretmesi istenmektedir. Diğer taraftan Avrupa Konseyine üye ülkelerde yaşayan her bireyin Sözleşmede düzenlenen haklarının ihlal edildiğine ilişkin her türlü şikayetlerini Mahkeme önüne getirme olanağının olumsuz etkilenmemesine özen gösterilmeye çalışılmıştır. Bu iki farklı yaklaşım tüm hazırlık çalışmaları boyunca etkin olmuş ve ikisinin bir noktada uzlaşması mevcut metni ortaya çıkarmıştır. $\mathrm{Bu}$ yeni kabul edilemezlik koşulunun etkisinin sınırlı olacağı öngörülmektedir. Şartın muhtemel etkilerine ilişkin olarak Çalışma grubu tarafından yapılan simülasyon çalışmasında 2003 yılı Şubat ayında kabul edilebilirlik kararı verilerek Daireye gönderilmiş toplam 406 başvurudan ancak 19 tanesinin (\% 5) bu hükümden etkileneceği tespit edilmiştir. ${ }^{45} \mathrm{Bu}$ şart özellikle başvurucunun önemli bir kayba uğramadığı benzer nitelikteki kopya (clone) başvurularda Mahkemeye geniş bir eleme yetkisi vermektedir. Mahkeme kararlarının taraf devletlerce uygulanmasını zorlayıcı tedbirlerin de bu Protokolle getirildiği dikkate alınırsa bu yeni kabul edilemezlik şartının başvurucular için olumsuz etkisinin oldukça azaldığı görülecektir.

\footnotetext{
${ }^{44}$ Dembour, s.610

${ }^{45} \mathrm{CM}(2003) 55$ s. 10
} 
Madde metni esastan incelemeyi gerektiren başvuruların başvurucunun kaybı önemsiz olsa bile reddedilmeden incelemesini zorunlu kılacak şekilde düzenlenmiştir. Dolayısıyla Sözleşmenin uygulanması ve yorumunu gerektiren ya da ulusal hukuku ilgilendiren önemli olaylar başvurucuların haklarına etkisi çok az bile olsa Mahkeme tarafından incelenecektir.

Elbette bu şartın nasıl uygulanacağı zamanla Mahkeme içtihatları ile açıklık kazanacaktır. Ve bu açıklık ortaya çıkıncaya kadar iki yıl boyunca bu şart sadece Daireler ve Büyük Daire tarafından uygulanacak Komite ve tek yargıç bu şartı uygulayamayacaktır. Böyle bir geçiş döneminin öngörülmesi oldukça isabetlidir, ancak bu sürede bu hükmün nasıl uygulanacağının ne kadar açıklıkla ortaya konulabileceği bir tartışma konusu olacaktır. Özellikle başvurucunun kaybının ne zaman önemsiz sayılacağı ve iç hukukta incelemenin yapılıp yapılmadığı ciddi tartışmalara yol açabilir ve bu sorunların çözümü Mahkemeye ilave iş yükü getirebilir.

Protokolün 13. maddesi Sözleşmenin 36. maddesine bir 3. paragraf ekleyerek Avrupa Konseyi İnsan Hakları Komiserine Daire ya da Büyük Daire önündeki başvurularla ilgili olarak yazılı yorum sunma ya da duruşmalara katılma şeklinde müdahalede bulunma imkanı getirilmiştir. Komiserin bu şekilde üçüncü şahıs olarak başvuruya müdahil olmasının bazı konularda Mahkemeye yardım edebileceği ve ortak faydayı sağlamaya yardımcı olacağı düșünülmektedir. Özellikle taraf ülkelerdeki bazı yapısal zayıflıklar konusunda Komiser Mahkemeyi aydınlatıcı bilgilere sahip olabilir ve bu bilgilerini Mahkemeye sunabilir. Elbette Komiserin bir taraf devlet aleyhine müdahalede bulunması devletle arasinda bir güven sorunu doğurabilir. Ya da bağımsız arabulucu vasfının ve saygınlığının zayıflamasına neden olabilir. $\mathrm{Bu}$ nedenle hazırlık çalışmaları sırasında Komisere başvuru hakkı tanınması önerisi taraftar bulamamıştır. ${ }^{46}$ Belki müdahilliğin başvuruculuğa göre daha tarafsız bir sıfat olduğu düşünülebilir ama yine de bu yetki çok dikkatle kullanılmalı ve Komiserin saygınlığını zedeleyici sonuçlar doğurmamalıdır. Bu hükümle Komiser ilk kez Sözleşme metnine girmektedir. Elbette bu hüküm tüm başvuruların Komisere bildirilmesini zorunlu hale getirmemektedir. Komiser kendisi bašvuru hakkında haberdar olursa bu yetkisini kullanabilecektir. Müdahillik hakkının nasıl kullanılacağının ayrıntıları Mahkeme içtüzügü ile tespit edilecektir.

Protokolün 14. maddesi başvurunun incelenmesini düzenleyen 38 . maddeyi değiştirmektedir. Buna göre 'Mahkeme, önündeki davayı tarafların temsilcileriyle birlikte inceler ve ihtiyaç hasıl olursa sorușturma açar ve ilgili taraf devletler bu soruşturmanın etkin bir şekilde yürütülmesi için her türlü kolaylıkları sağlarlar.' Bu maddede yapılan değişikliklerden ilki daha önceki metinde yer alan kabul edilebilirlik kararı verildikten sonra ibaresinin metinden çıkarılmasıdır. Böylece 28 ve 29. maddelerde kabul edilebilirlik ve

${ }^{46}(\mathrm{CM}(2003) 55 \mathrm{~s} .18$ 
esas hakkındaki kararların birlikte alınması yönünde yapılan değişikliklere paralel olarak kabul edilebilirlik kararı verilmeden önce de soruşturma yapılması mümkün hale getirilmiş ve taraf devletlere bu aşamada da her türlü kolaylığı sağlama yükümü getirilmiştir. İkinci değişiklik ise eski 38. maddenin $1 / \mathrm{b}$ fikrası ve 2 . paragrafinda yer alan dostane çözümle ilgili hükümlerin bu maddeden çıkarılmasıdır. Dostane çözüme ilişkin hüküm sonraki madde ile ayrıntılı olarak düzenlenmiştir.

Protokolün 15. maddesi dostane çözüme ilişkin 39. maddeyi yeniden düzenlemektedir. Yeni 39. maddenin ilk üç paragrafı eski 38. ve 39. maddelerden alınmış ve yeni bir dördüncü paragraf eklenmiştir. Buna göre '1. İncelemenin her aşamasında Mahkeme davanın Sözleşme ve Protokollerinde tanımlanan insan haklarına saygı temelinde bir dostane çözümle sonuçlanması için taraflara yardım etmeye hazır olacaktır. 2. Birinci paragrafta belirtilen faaliyetler gizli yürütülecektir. 3. Eğer bir dostane çözüme ulaşılırsa Mahkeme olayların kısa özeti ve ulaşılan çözümü içeren bir kararla davayı Mahkeme listesinden çıkarmaya karar verir. 4. Bu karar ulaşılan çözümün yerine getirilmesini gözlemek üzere Bakanlar Komitesine gönderilir.' Bu şekilde dostane çözüme ilişkin tüm hükümler aynı maddede toplanarak Sözleşmenin sistematiği düzeltilmiş ve okunması daha kolay hale getirilmiştir. İkinci olarak dostane çözüm arayışına girişebilmek için kabul edilebilirlik kararının beklenmesi gerekmeyecektir. İncelemenin her aşamasında dostane çözüm girişimlerinde bulunulabilecektir. Son olarak dostane çözüm kararının da (decision) uygulanmasını gözetleme görevi Bakanlar Komitesine verilmektedir. Bu hüküm aslında Mahkeme tarafindan geliştirilen uygulamanın Sözleşmeye yansıtılmasından ibarettir. ${ }^{47}$ Çünkü Mahkeme dostane çözüm kararlarını eski 39. maddeye (decision) göre değil 46/2. maddeye göre (judgment) vermekte ve böylece uygulamasını Bakanlar Komitesinin denetimine tabi hale getirmekteydi. Getirilen değişiklikle dostane çözüm kararı decision şeklinde verilse de diğer kesin hüküm niteliğindeki Mahkeme kararları (judgments) gibi uygulanması Bakanlar Komitesinin gözetimine verilmektedir. Böylece taraf devletler açısından dostane çözüm arayışlarına girmek daha kolay hale getirilmiştir. ${ }^{48}$

Protokolün 16. maddesi Mahkeme kararlarının bağlayıcılığını düzenleyen 46. maddeye üç yeni paragraf (3., 4. ve 5. paragraflar) eklemektedir. Bunlardan ilki Bakanlar Komitesine bir Mahkeme kararının yerine getirilmesinin gözetiminde yorum problemi ile karşılaşması halinde 2/3 çoğunlukla kararın Mahkeme tarafından yorumlanmasını isteme yetkisi tanımaktadır. Bu hüküm Bakanlar Komitesinin bir kararın içeriğinin ne olduğunu yorumlama konusunda uygulamada karşılaştı̆̆ 1 problemlere bir çözüm getirmeyi amaçlamaktadır. Komitede bir kararın ne anlama geldiği konusunda bir görüş ayrılığı çıkarsa, Komite Mahkemeden kararının ne

${ }^{47} \mathrm{ER}, \S 93$

${ }^{48}$ CDDH-GDR(2001)010, s.8 
anlama geldiğini açıklamasını isteyebilecektir. Ancak böyle bir talepte bulunabilmesi için, üçte iki nitelikli çoğunluğun oyuna ihtiyaç vardır ki, bu yönde çok fazla taleple Mahkemenin iş yükü artırılmasın, sadece önemli uyuşmazlıklarda bu yola başvurulabilsin. Bu paragrafin amacı Mahkemenin taraf devletin aldığı tedbirlerin kararın gereğini yerine getirip getirmediğine karar vermesi değildir. Sadece kararın ne anlama geldiğine karar verecektir. Kararı Mahkemenin hangi organı vermişse yorumu da o organ yapacaktır. ${ }^{49}$

İkinci önemli değişiklik, Bakanlar Komitesine, Sözleşmeye taraf devletlerden birisi taraf olduğu bir davada Mahkeme tarafindan verilen nihai karar1 uygulamayı reddederse, bir uyarıdan sonra o devletin Mahkeme kararına uyup uymadığ1 konusunda karar vermesi için üçte iki çoğunlukla Mahkemeye başvurma yetkisi tanınmasıdır. Bu başvuruyu Mahkemenin Büyük Dairesi inceleyecektir. Eğer Mahkeme taraf devletin Mahkeme kararına uyma yükümünü ihlal ettiğine karar verirse, dosyayı gerekli tedbirleri alması için Bakanlar Komitesine gönderir, ihlal etmediğine karar verirse, dosyanın incelemesini kapatması için yine Bakanlar Komitesine gönderir.

İnsan hakları ihlallerinin sona erdirilmesi ve Mahkemeye gelen başvuruların sayısının azaltılması için Mahkeme kararlarının süratle uygulanması hayati öneme sahiptir. Özellikle ihlal yapısal bir nedenden kaynaklanıyorsa bu yapısal bozukluğun süratle giderilmemesi Mahkemeye benzer pek çok başvurunun gelmesine neden olacak ve Mahkemenin iş yükünü önemli ölçüde artıracaktır. Ayrıca Mahkemenin etkinliğinin ve saygınlığının korunması kararlarının etkin bir şekilde uygulanması ile mümkündür. Mahkeme kararlarının uygulanmasını gözetleme görevi Bakanlar Komitesine verilmiştir. Komitenin Mahkeme kararlarını uygulamay1 1srarla reddeden taraf devletleri karara uymaya zorlayıc1 yaptırımların yeterli olmadığı ve yeni bazı baskı araçlarına ihtiyaç olduğu hazırlık çalışmaları sırasında dile getirilmiş ve Mahkeme kararlarının etkin uygulamasını sağlayıcı diğer tedbirler arasında birde Bakanlar Komitesine Mahkemeye bu konuda bir karar vermesi için başvuru hakkı tanınması gündeme gelmiştir. Ayrıca ilgili devletin Mahkeme kararına uymadığının tespiti halinde bir de Avrupa Konseyine ödenmek üzere maktu bir para cezasına hükmedilmesi de önerilmiş fakat para cezası yaptırımı kabul görmemiştir. ${ }^{50}$

Mahkeme Kararının gereklerinin ne olduğunu tespit hususunda devletlerin sahip olduğu takdir yetkisi korunmuştur. Yani istisnalar dışında Mahkeme gene Mahkeme kararının yerine getirilmesi için taraf devletin neler yapması gerektiğine karar veremeyecektir. Mahkeme sadece ihtiyati tedbir olarak devletlere yapmaları ya da yapmamaları gereken hususlarda

${ }^{49} \mathrm{ER}, \S 96$

${ }^{50} \mathrm{CM}(2003) 55$, s. 14 
talimat verebilmektedir. Mesela idam cezasinın uygulanmasının durdurulması ya da iade kararının uygulanmasının ertelenmesi gibi. Bunun dışında bazı başvurularda Mahkeme seçimlik olarak eski hale iade (restitutio in integrum) kararı vermiştir. ${ }^{51} \mathrm{Bu}$, Sözleşmenin koruma mekanizmasının ikincil (subsidiary) nitelikte olmasının doğal bir sonucudur. Kanımızca, bu husus da ileride tartışmaya açılmalı ve Mahkemenin Amerikan İnsan Hakları Mahkemesi gibi devletlerin somut bir takım tedbirler almasına hükmeden kararlar alabilmesinin yolu açılmalıdır. Şimdilik böyle bir yetki tanınmamış olsa da getirilen başvuru hakkı Komiteye devletleri Mahkeme kararının gereklerine uyma konusunda baskı yapmasina imkan tanıyacaktır. $\mathrm{Bu}$ özellikle yapısal sorunlardan kaynaklanan ihlallerde devletin yapısal problemi sona erdirici tedbirler almaya zorlanması ile benzer başvuruların Mahkemenin önüne gelmesini engelleyerek iş yükünde önemli bir azalma meydana getirecektir.

Komite bu başvuru yoluna ancak istisnai hallerde taraf devletin Mahkeme kararına bilerek 1srarla uymaması halinde müracaat edecek, dolayısıyla Mahkeme açısından yeni bir iş yükü kaynağı olmayacaktır. Bunun için, hem önce taraf devlete bildirimde bulunma zorunluluğu getirilmiş, hem de $2 / 3$ nitelikli çoğunluk aranmıştır. Ayrıca bu inceleme sırasında ihlalin olup olmadığ kesinlikle yeniden tartışmaya aç1lmayacaktır. ${ }^{52}$

Sözleşmede son bir değişiklik Protokolün 17. maddesi ile 59. maddede yapılmaktadır. 59. maddeye yeni bir 2. paragraf eklenerek Avrupa Birliğinin Sözleşmeye taraf olabileceği hükmü Sözleşmeye girmiştir. Avrupa Birliğinin 25 üyesinin tamamının aynı zamanda Avrupa Konseyi üyesi ve Sözleşmeye taraf olması nedeniyle bu ülkelerin vatandaşlarının Birlik hukukunun uygulanmasından ya da Birlik kurumlarının uygulamalarından kaynaklanan Sözleşmeye aykırılık iddialarının Mahkeme tarafından incelenebilmesi için Birliğin Sözleşmeye taraf olması gerekmektedir. Reform çalışmaları sırasında bu problem de inceleme konusu yapılmış ve Birliğin Sözleşmeye taraf olmasının önündeki hukuki ve teknik engellerin kaldırılması için yapılması gerekenler ortaya konulmaya çalışılmıştır. İnsan Hakları Yönlendirme Komitesi (CDDH) tarafindan 2002 yllında bu konuda bir rapor $^{53}$ hazırlanarak Birliğin Sözleşmeye katılmasının muhtemel farklı formülleri ortaya konulmuştur. Bu konuya ilişkin çalışmalar daha sonra da devam etmiş farklı formüller üzerinde çalışılmıştır. ${ }^{54}$ Temelde iki farklı formül ortaya konulmuştur: Birliğin katılması ya Sözleşmenin yeni bir

51 Papamichalopoulos/Yunanistan, 24 Haziran 1993 Series A No.260-B; Brumerascu/Romanya, 28.11.1999, Baş.No.28342/95; Vasiliu/ Romanya, 21 Mayıs 2002, Baş. No. 29407/96

${ }^{52} \mathrm{ER} \$ 99$

${ }^{53} \mathrm{CDDH}(2002) 010$ Addendum 2

${ }^{54}$ CDDH-GDR(2003)025 
Protokolle değiștirilmesi ya da Sözleşmeye taraf devletler ile Birlik arasında bir katılım anlaşması yoluyla yapılması öngörülmektedir. Yönlendirme Komitesi katılım anlaşması yolunu tercih etmesine rağmen Protokole bunu koymayı gelecekte değişik ihtimalleri açık bırakmak için uygun bulmamıştır. Ancak Birliğin henüz kendi Anayasasını hazırlama aşamasında olması nedeniyle şu anda Sözleşmeye katılma yetkisine sahip olmaması katılım konusunun şu anda sonuçlanmasına imkan vermemektedir. $\mathrm{Bu}$ nedenle katılım halinde gerekli detaylı değişiklikler sonraya bırakılarak Protokole sadece Birliğin Sözleşmeye katılmasına imkan tanıyan bir hüküm konulması ile yetinilmiştir. ${ }^{55}$

Protokolün 18-22 maddeleri geçici ve son hükümlere ayrılmıştır. Protokolün imza, onay ve yürürlüğe girmesine ilişkin bu hükümler uluslararas1 Sözleşmelerin olağan hükümleridir. Protokole çekince konulmasına izin verilmemiştir. Protokol tüm taraf devletlerce onaylanmasından üç ay sonra yürürlüğe girecektir. Yürürlüğe girdiği tarihte Mahkemede görüşülmekte olan tüm başvurulara ve uygulaması gözetim altında olan tüm kararlara uygulanacak, ancak 35. maddeye eklenen yeni kabul edilemezlik şartı yürürlüğe giriş tarihinden önce kabul edilebilirlik kararı verilmiş başvurular için uygulanmayacak ve yeni kabul edilemezlik şartı yürürlük tarihinden itibaren iki yıl boyunca Mahkemenin sadece Büyük Daire ve Daireleri tarafindan uygulanabilecektir. Ayrıca Mahkeme yargıçlarından yürürlüğe girme anında ilk dönem görev yapanların süresi otomatik olarak dokuz yıla uzayacak, diğer yargıçların görevleri normal süreleri sonunda sona erecektir.

Protokolü 3 Şubat 2005 tarihi itibariyle otuz bir ülke ${ }^{56}$ imzalamıştır, bunlardan yedisi ${ }^{57}$ onaylamıştır. Türkiye Protokolü 6 Ekim 2004 tarihinde imzalamış fakat henüz onaylamamıştır.

\section{Sonuç ve Değerlendirme}

14. Protokolün getirdiği değişikliklerin Avrupa İnsan Hakları Mahkemesinin hem incelenemez nitelikteki başvuruları eleme kapasitesini hem de Mahkemenin yerleşik içtihadının uygulanacağı standart başvuruları kısa zamanda sonuçlandırma yeteneğini önemli ölçüde artıracağ 1 muhakkaktır. $\mathrm{Bu}$ tedbirlerin yürürlüğe girmesi halinde Mahkemenin iş yükü sorununun önemli ölçüde hafifleyeceğini tahmin etmek de pek zor olmasa

\footnotetext{
${ }^{55} \mathrm{ER}, \S 101,102$

${ }^{56}$ Arnavutluk, Andorra, Avusturya, Almanya, Bosna-Hersek, Ermenistan, Hirvatistan, Kibris, Danimarka, Estonya, Finlanda, Fransa, Gürcistan, Yunanistan, İzlanda, İrlanda, İtalya, Letonya, Lihteştayn, Litvanya, Lüksemburg, Malta, Moldova, Monako, Hollanda, Norveç, Polonya, Portekiz, Romanya, Sırbistan-Karadağ, Slovakya, Slovenya, İsveç, İsviçre, Makedonya, Türkiye, Ukrayna, İngiltere

${ }^{57}$ Ermenistan, Danimarka, Gürcistan, İrlanda, Malta, Norveç, İngiltere
} 
gerektir. Ancak Mahkemenin karar verme kapasitesi ve hizı ne kadar artırılırsa artırılsın, Avrupa Konseyine üye 45 devlette yaşayan yaklaşık 800 milyon insanın tüm insan hakları sorunlarına mevcut 45 yargıçlı tek Mahkemenin cevap vermesini ummak akla yatkın gözükmemektedir. Sözleşme ve eklerinde garanti altına alınan hakları kendi yargı yetkisi altında yaşayan bireylere sağlama yükümlülüğü birinci derecede Sözleşmeye taraf devletlere ait olduğundan, taraf devletler bu yükümlülüğü milli düzeyde yerine getirmek için her türlü tedbirleri almalı, uluslararası ya da ulusalüstü koruma mekanizmasının koruma fonksiyonunun ikincil (subsidiary) niteliği gereği Mahkeme sadece Sözleşmenin uygulanmasına ilişkin temel problemleri çözecek içtihatları oluşturma işlevini yürütmelidir.

Bunun için Mahkemenin mevcut işlevlerinin değiştirilmesi gerekmez. Ancak, taraf devletler Sözleşmeyi kendi ülkelerinde eksiksiz uygulamak için gerekli her türlü tedbiri alırlar ve mekanizmaları kurarlarsa, Mahkemenin önüne gelen başvuru sayısı önemli ölçüde düşecek ve Mahkemenin esastan incelemesini gerektiren başvuru sayısı da oldukça azalacaktır. Hazırlık çalışmaları sırasında bu durum ortaya konularak Sözleşmeyi uygulamak için taraf devletlerin yerel düzeyde alması gereken tedbirlere ilişkin Avrupa Konseyinin tavsiye ve önerileri Bakanlar Komitesi Bildirgesi ya da Tavsiyesi şeklinde ortaya konulmaya çalışılmıştır. Yerel düzeyde yapılması gerekenler bir kaç başlıkta toplanabilir:

Öncelikle yerel mevzuatın Sözleşmeye uyumlu hale getirilmesi gerekmektedir. Buna yeni yapılacak yasalar da dahildir. Dolayısıyla mevzuat taslaklarının Sözleşmeye uyum açısındanda değerlendirilmesi ve kontrol edilmesi gerekir.

İkinci olarak, hukuk uygulayıcılarının Sözleşme ve Mahkeme içtihadı açısından eğitilerek hukuk uygulamasının Sözleşmeye uyumlu hale getirilmesi gerekmektedir. Bunun için hem, üniversite ve mesleki eğitimde Sözleşmenin yeterince yer alması gerekmekte hem de Sözleşme ve ekleri ile ilgili Mahkeme içtihadının taraf devletlerin kendi dillerinde yayınlanarak ilgililer tarafindan kolayca ulaşılabilir hale getirilmesi gerekmektedir. Hukukçular gerekirse hizmet içi eğitime tabi tutulabilir. Üçüncü olarak, Mahkeme kararlarının taraf devletlerce kısa sürede uygulanması için gerekli yasal altyapının hazırlanması gerekmektedir. Bunun için taraf devletler ihlalin kaynağına göre çeşitli tedbirler almalıdırlar. Mesela ihlal kesinleşmiş bir yarg1 kararının uygulanmasından kaynaklanıyorsa, bu yargı kararının değiştirilebilmesi için Mahkeme kararının bir yargılamanın iadesi sebebi sayılması gerekebilir. Ya da bir yasanın uygulanması ihlal nedeni ise, sadece o yasanın değiştirilmesi geçmiş uygulamalardaki Sözleşmeye aykırılığı ortadan kaldırmayacağından, geçmiş ihlalleri düzeltecek yasaların çıkartılması gerekebilir. Dördüncü olarak, Sözleşmeye aykırılık iddialarını ulusal düzeyde inceleyecek mekanizmalar oluşturularak iç hukuk yolları arasına bu mekanizmalar katılabilir. Mesela Sözleşmeye aykırılık iddiaları bireysel anayasal şikayet konusu yapılabilir ya da Sözleşmeye aykırılık 
iddialarını ulusal düzeyde nihai olarak inceleyecek bir ombudsman kurumu oluşturulabilir. Ancak ulusal düzeyde bu tedbirler alınırsa, Mahkemenin iş yükü problemi başedilir hale gelebilir; aksi takdirde, Mahkemenin eleme ve karar alma kapasitesi ne kadar artırılırsa artırılsın, kısa süre sonra bu yük baş edilebilir olmaktan çıkacaktır.

Yukarıda bahsedilen hususlardan önemli bir kısmı Bakanlar Komitesi tarafindan taraf devletlerin dikkatine sunulmuştur. İlk olarak, Bakanlar Komitesi Mahkemenin kesinleşmiş yerel mahkeme kararlarının Sözleşmeyi ihlal ettiğine karar vermesi halinde, Mahkemenin bu tür kararlarının yerel düzeyde yargılamanın iadesi nedeni sayılmasını tavsiye etmiştir. ${ }^{58}$ Daha sonra 2002 yılında, Komitenin Avrupa İnsan Hakları Sözleşmesi metninin ve Mahkeme kararlarının taraf ülkelerde basılması ve yaygın şekilde dağıtılmasını tavsiye eden kararı yayınlanmıştır. ${ }^{59}$ Yine 12 Mayıs 2004 tarihinde Komite, Sözleşmenin ve Mahkeme içtihatlarının taraf ülkelerde hem hukuk, kamu yönetimi ve siyaset bilimi gibi yüksek öğretim programlarında zorunlu ders olarak okutulmasını, hem de yargıçlık ve avukatlık eğitim ve sınavlarında Sözleşmeye yer verilmesini tavsiye eden bir $\operatorname{karar}^{60}$ yayınlamıştır. Aynı tarihte Komite iki tane daha tavsiye kararı yayınlamıştır: Bunlardan ilki yasa tasarılarının ve mevcut mevzuat ve uygulamanın Sözleşme ve Mahkeme içtihatlarına uyumunu gözetleyecek mekanizmaların kurulması ve aykırılıkların kısa sürede giderilmesi için gerekli önlemlerin alınmasına ilişkindir. ${ }^{61}$ Diğeri ise Sözleşmenin ihlali iddialarının ulusal düzeyde etkin bir şekilde incelenmesine ve ihlalin sona erdirilmesine imkan veren başvuru yollarının oluşturulmasını ve geliştirilmesini tavsiye etmektedir. ${ }^{62}$ Dolayısıyla Sözleşmeyi uygulamak birinci derecede taraf devletlerin yükümlülügündedir ve devletler bu yükümlülüklerini yerine getirmek için gerekli her türlü tedbiri kısa zamanda almalıdır ki, Avrupa İnsan Hakları Mahkemesinin etkinliği ve saygınlığı korunabilsin ve sürdürülebilsin.

\footnotetext{
${ }^{58}$ Recommendation No. R(2000)2) (Recommendation of the Committee of Ministers of 19 January 2000 on the re-examination or reopening of certain cases at domestic level following judgments of the European Court of Human Rights

${ }_{59} \operatorname{Rec}(2002) 13$ Recommendation of the Committee of Ministers on the publication and dissemination in the member states of the text of the European Convention on Human Rights and of the case-law of the European Court of Human Rights.

${ }^{60} \operatorname{Rec}(2004) 4$ Recommendation of the Committee of Ministers to member states on the European Convention on Human Rights in university education and professional training.

${ }^{61} \operatorname{Rec}(2004) 5$ Recommendation of the Committee of Ministers to member states on the verification of the compatibility of draft laws, existing laws and administrative practice with the standards laid down in the European Convention on Human Rights

${ }^{62} \operatorname{Rec}(2004) 6$ Recommendation of the Committee of Ministers to member states on the improvement of domestic remedies
} 


\section{YARARLANILAN KAYNAKLAR}

Council of Europe, Explanatory Report to the CETS 194 (Protocol No.14 to the Convention for the Protection of Human Rights and Fundamental Freedoms, amending the control system of the Convention)

Council of Europe, Committee of Ministers, Decleration on the protection of Human Rights in Europe -Guaranteeing the long-term effectiveness of the European Court of Human Rights, 8 November 2001

Council of Europe, Committee of Ministers, Decleration on the Court of Human Rights for Europe, 7 November 2002

Council of Europe, Committee of Ministers, Decleration Guaranteeing the long-term effectiveness of the European Court of Human Rights, 15 May 2003

Council of Europe, Committee of Ministers, Decleration Ensuring the effectiveness of the implementation of the European Convention on Human Rights at national and European levels, 13 May 2004-09-13

Council of Europe, Committee of Ministers, Recommendation of the Committee of Ministers on the re-examination or reopening of certain cases at domestic level following judgments of the European Court of Human Rights, 19 January 2000) (Recommendation No. R(2000)2

Council of Europe, Committee of Ministers, Recommendation of the Committee of Ministers on the publication and dissemination in the member states of the text of the European Convention on Human Rights and of the case-law of the European Court of Human Rights, Recommendation No. $(\operatorname{Rec}(2002) 13)$

Council of Europe, Committee of Ministers, Recommendation of the Committee of Ministers to member states on the European Convention on Human Rights in university education and professional training , 12 May 2004, $(\operatorname{Rec}(2004) 4)$

Council of Europe, Committee of Ministers, Recommendation of the Committee of Ministers to member states on the verification of the compatibility of draft laws, existing laws and administrative practice with the standards laid down in the European Convention on Human Rights, 12 May 2004, $(\operatorname{Rec}(2004) 5)$

Council of Europe, Committee of Ministers, Recommendation of the Committee of Ministers to member states on the improvement of domestic remedies , 12 May 2004, $(\operatorname{Rec}(2004) 6)$

Dembour, Marie-Benedicte (2002) “Finishing off' Cases:The Radical Solution to the Problem of the Expanding ECTHR Caseload" European Human Rights Law Review, 5, 604-623 
European Court of Human Rights, Survey of Activities 2003 (http://www.echr.coe.int/Eng/EDocs/2003SURVEYCOURT.pdf)

Evaluation Group, Report of the Evaluation Group to the Committee of Ministers on the European Court of Human Rights, (EG Court(2001)1) 27 September 2001

Steering Committee for Human Rights (CDDH), Reflection Group on the Reinforcement of the Human rights Protection Mechanism (CDDH-GDR), Activity Report, (CDDH-GDR(2001)010), 15 June 2001

Steering Committee for Human Rights (CDDH), Interim Report of the $\mathrm{CDDH}$ to the Committee of Ministers 'Guaranteeing the long-term effectiveness of the European Court of Human Rights', (CM(2002)146), 18 October 2002

Steering Committee for Human Rights (CDDH), Final Report containing proposals of the CDDH 'Guaranteeing the long-term effectiveness of the European Court of Human Rights', (CM(2003)55), 8 April 2003

Steering Committee for Human Rights (CDDH), Interim Activity Report 'Guaranteeing the long-term effectiveness of the European Court of Human Rights'-Implementation of the Decleration adopted by the Committee of Ministers at its 122th session, $(\mathrm{CDDH}(2003) 026$ Addendum I Final), 26 November 2003

Steering Committee for Human Rights (CDDH), Final Activity Report of the $\mathrm{CDDH}$ to the Committee of Ministers 'Guaranteeing the long-term effectiveness of the European Court of Human Rights', (CM(2004)65), 8 April 2004 